\title{
THE OUTLOOK FOR FEDERAL RESERVE AND TREASURY POLICY*
}

\author{
WARREN L. SMIth \\ University of Michigan and Harvard University
}

\section{INTRODUCTION}

THE OUTLOOK FOR monetary and fiscal policy for the next year must obviously be considered in the context of the general economic outlook. This is particularly true of monetary policy, since the administrative flexibility possessed by the Federal Reserve System permits continuous adaptation of monetary controls to the changing state of the economy. Fiscal developments, at least for the first half of the year, are a bit easier to predict, because, in the absence of major changes in the international situation or in the domestic economy, there is likely to be little discretionary fiscal adjustment until the 1960 budget goes into effect at midyear. Accordingly, I shall review briefly probable budgetary developments and then consider the general economic situation and the outlook and problems that seem likely to confront the Federal Reserve during 1959.

\section{The Fiscal Outlook}

Based on daily Treasury statements through early December, it appears that Treasury cash payments to the public for the second half of (calendar) 1958 will be roughly $\$ 45.9$ billion, with cash receipts for the same period amounting to about $\$ 34.6$ billion. On this basis, the cash deficit for the second half will be about $\$ 11.3$ billion. According to the September budget review, the corresponding amounts for the entire fiscal year 1959 are cash expenditures $\$ 94.1$ billion, receipts $\$ 80.4$ billion, and cash deficit $\$ 13.7$ billion. $^{1}$ If these estimates turn out to be correct, cash outlays in the first half of 1959 will amount to roughly $\$ 48.2$ billion, with receipts $\$ 45.8$ billion, and a cash deficit of $\$ 2.4$ billion. Recent reports, however, suggest that increased military outlays and higher farm price-support costs will boost expenditures by something in the neighborhood of a billion dollars. ${ }^{2}$ At the same time, since recovery has almost certainly pro-

* The author wishes to express his appreciation to Professor John Lintner for many helpful criticisms of an earlier draft of this paper.

1. 1959 Federal Budget Midyear Review (Washington: Bureau of the Budget, 1958).

2. Wall Street Journal, December 10, 1958, p. 2. 
ceeded at a faster pace than was expected at the time the midyear budget review was prepared, receipts-particularly from the personal income tax-will probably be somewhat higher than was then foreseen. Thus a cash deficit of about $\$ 2.4$ billion seems a reasonable estimate.

On the basis of the above estimates, cash outlays will probably be in the neighborhood of $\$ 49$ billion in the first half of 1959 , or about $\$ 3$ billion greater than in the last half of 1958 . On the other hand, cash receipts will probably run around $\$ 46.5$ billion, or about $\$ 12$ billion higher than in the second half of 1958 . A considerable part of this increase in receipts will be due to the operation of seasonal factors, such as the concentration of collections under the corporate income tax in the first half of the calendar year. In addition, the projected increase is due partly to the expectation of rising incomes resulting from recovery.

According to its September projections, the Treasury planned to finance $\$ 6$ billion of the cash deficit in fiscal 1959 by reducing the balance in the general fund, which amounted to the unusually high total of $\$ 9.7$ billion in June, $1958 .^{3}$ In view of the size of the balance in the general fund and the prospective deficit remaining as of early December, it appears that net cash borrowing of something in the neighborhood of $\$ \frac{1}{2}$ billion will be necessary in the first half of 1959 . Gross borrowings will be much larger than this, however, because of the unevenness of tax receipts, which are heavily concentrated in March and June. The Treasury plans to raise about $\$ 2.6$ billion of new money through the first quarter in connection with the issuance of the new series of $26-$ week bills. Another $\$ 1.5-\$ 2.0$ billion is apparently to be raised through the issuance of additional securities for cash in January. ${ }^{4}$

Treasury refunding operations should be a somewhat less worrisome problem in 1959 than during the past year. The largest operation occurs early in the year-in February-when $\$ 14.9$ billion of refinancing comes up. However, the Federal Reserve System and the Treasury investment accounts hold $\$ 5.8$ billion of the two issues maturing at that time, leaving $\$ 9.1$ billion of publicly held securities to be refunded. Another large refunding - a $\$ 13.5$ billion issue of certificates-is scheduled for August. The Federal Reserve and Treasury investment accounts hold $\$ 8.3$ billion of this issue, the re-

3. Federal Government Receipts from and Payments to the Public, Supporting Tables, Fiscal Years 1958 and 1959 (Washington: Bureau of the Budget, September, 1958), p. 11.

4. New York Times, November 19, 1958, p. 53. 
maining $\$ 5.2$ billion being publicly held. The only other refunding operation of any size comes up in November and involves two issues aggregating $\$ 8.9$ billion. Two issues of Treasury bonds reach their first call dates during 1959, one in June and one in December. The June issue amounts to $\$ 5.3$ billion and the December issue $\$ 3.5$ billion. Whether or not these issues will be refunded in 1959 will presumably depend upon how interest rates and the state of the security markets in 1959 compare with what the Treasury foresees in this regard for the period up to 1962, when both issues reach their final maturity. Very likely, refunding will be postponed. In general, it would appear that problems of debt management should interfere relatively little with the freedom of action of the Federal Reserve during 1959.

\section{The General Economic Outlook}

Gross national product in real terms (valued at 1954 prices) fell from a peak level of $\$ 409.6$ billion in the third quarter of 1957 to $\$ 386.7$ billion in the first quarter of 1958 , a drop of 5.6 per cent. By the third quarter of 1958 , GNP had risen to $\$ 396.9$ billion, a rise of 2.6 per cent. It has been estimated that GNP at current prices in the fourth quarter will be approximately $\$ 450$ billion. Assuming that no rise in prices occurs from the third to the fourth quarter, this will represent an output of about $\$ 406$ billion valued at 1954 prices. $^{5}$ Thus it appears that, by the fourth quarter, the economy will have moved in real terms nearly back to the peak level of the third quarter of 1958. Although the original decline was the largest and most rapid of the postwar period, the recovery through the fourth quarter appears to have been quite satisfactory. However, there is still a surprisingly large amount of unemployment-amounting in November to 3.8 million workers or 5.9 per cent of the labor force on a seasonally adjusted basis.

Between the first and third quarters of 1958 , GNP valued at current prices rose by $\$ 13.2$ billion. The main factors responsible for this expansion were a rise of $\$ 3.8$ billion in government purchases ( $\$ 2.5$ billion federal and $\$ 1.3$ billion state and local), a decline of $\$ 4.5$ billion in the rate of inventory disinvestment, and an increase of $\$ 5.3$ billion in personal consumption expenditures. Business outlays on plant and equipment continued their earlier decline, although at a much reduced rate, but this decline was partially offset by a

5. These and later calculations were based on the assumption that the implicit price deflator for GNP has moved in the same proportion as the movements in the average of the indices of consumer prices and wholesale prices. 
slight pickup in residential construction. Consumer expenditures on durable goods also continued to decline, but at a reduced rate; however, this decline was far more than offset by substantial increases in expenditures on non-durable goods and services.

The marginal propensity to consume out of GNP has been rather small during the present recession both on the downswing and in the upswing through the third quarter of 1958 . In the downswing from the third quarter of 1957 to the first quarter of 1958, this was due both to a small decline in disposable income relative to the fall in GNP-resulting from an increase in transfer payments, stability of dividends in the face of a sharp decline in corporate profits, and a fall in personal taxes-and to a small decline in consumption expenditures relative to the drop in disposable income. Thus, while GNP fell by $\$ 19.8$ billion, disposable income fell by only $\$ 3.7$ billion, and consumption expenditures by $\$ 2.1$ billion. From the first to the third quarters of 1958 , disposable income rose more rapidly relative to GNP than it had fallen during the decline-a rise of $\$ 13.2$ billion in GNP being accompanied by a rise of $\$ 9.0$ billion in disposable income. However, personal consumption expenditures rose by only $\$ 5.3$ billion. The marginal propensity to consume out of disposable income was only about 60 per cent during the downswing and about the same during the first two quarters of the upswing. This contrasts with a marginal propensity to consume of nearly 95 per cent during the long upswing from the second quarter of 1954 to the third quarter of 1957. Taking account of the relation between disposable income and GNP, consumption expenditures rose by roughly 60 per cent of the rise in GNP during this period, as compared with a 40 per cent ratio during the first two quarters of the present upswing. This is a manifestation of the well-known ratchet effect. ${ }^{6}$ Multiplier effects working through consumption have thus been rather small in the recovery so far. However, when real per capita disposable income rises above its previous peak level of the third quarter of 1957which it had not yet done as of the third quarter of 1958-we can presumably expect a more pronounced response of consumption to further rises in income.

The important question for early 1959 is whether the autonomous

6. J. S. Duesenberry, Income, Consumption, and the Theory of Consumer Behavior (Cambridge, 1949). It should be noted that the ratios referred to above are computed from current dollar aggregates undeflated for population and price changes. If the data are deflated, the marginal propensity to consume is increased during the downswing and decreased during the upswing in 1957-58. However, deflation raises the marginal propensity to consume during the 1954-57 upswing, so that the contrast drawn above is actually sharpened. 
forces making for recovery will be strong enough to continue pushing the economy upward at a rapid rate. The latest Department of Commerce survey of business investment plans indicates that plant and equipment expenditures continued to decline in the third quarter of 1958 and will show only fractional increases in the fourth quarter and in the first quarter of $1959 .^{7}$ The McGraw-Hill survey likewise does not indicate an early recovery for plant and equipment expenditures. Some increases in government purchases can certainly be expected, at both the federal and the state and local levels. But it is difficult to see how these could rise by more than $\$ 2-\$ 3$ billion in the first quarter and another $\$ 1-\$ 2$ billion in the second (seasonally adjusted annual rates). Housing starts have been rising steadily on a seasonally adjusted basis, and maintenance of the present level or perhaps a small increase may be expected in early 1959. But this is unlikely to be a significant expansive factor; moreover, as pointed out below, housing may be adversely affected by rising interest rates. I see little else that can be depended upon. Of course, there will be an induced increase in consumption which could become a somewhat more powerful factor if the ratchet effect comes into play, as suggested above. In addition, it appears that the decline in inventories may have bottomed out in October, and some impetus can be expected from the inventory accelerator. However, the potency of the inventory expansion depends to some extent upon the strength of the basic forces at work. ${ }^{8}$ Moreover, inventories have been our most serious destabilizer in recent years, and it would seem desirable to begin thinking about ways to prevent an excessively rapid inventory buildup rather than rely upon inventory investment as a recovery device.

If these observations are correct, they suggest a possible slowingdown of the pace of recovery in the early part of 1959 . Of course, if we were nearing capacity operations, a slowing-down of expansion would perhaps be all to the good. However, I believe we are still rather far from realizing a level of output of goods and services that in any sense represents practical full-capacity production. I shall attempt to justify this view in the next few paragraphs.

One of the most curious features of the American economy during the postwar period is the erratic fashion in which productivity has changed. The year-to-year changes in average output per worker have varied between zero in 1956 and 5.9 per cent in 1950. ${ }^{9}$ The

7. Wall Street Journal, December 10, 1958.

8. The possibility of a steel strike at midyear may stimulate some abnormal inventory accumulation in the second quarter. 
largest increases were in 1950, 1951, and 1955; in the latter two years the increases were 3.3 and 5.4 per cent, respectively. In addition to 1956, when no change at all occurred, the smallest changes were in 1949 (1.5 per cent), 1954 (0.2 per cent), and 1957 (1.2 per cent). A moderate increase of 2.5 per cent appears to have occurred in $1958 .^{10}$

It is interesting to note that the years 1950 and 1955 which followed our two earlier postwar recessions showed by far the largest increases. In each of these years there were substantial reductions in unemployment as a per cent of the labor force. In addition, in the year 1951 when unemployment showed the sharpest drop from the preceding year of the entire postwar period (from 5.3 to 3.3 per cent of the labor force) there was a very substantial increase in output per worker.

Following the unusually large increase in 1955 , productivity experienced unusually small increases in 1956 and 1957 and only a moderate increase in 1958. These small increases are rather curious in light of the fact that gross investment in fixed capital (new construction and producers' durable equipment) amounted to $\$ 56.4$ billion in 1955, $\$ 57.6$ billion in 1956, and $\$ 56.4$ billion in 1957 (all valued at 1954 prices), amounts larger than in any other postwar years. Gross investment in 1958 will probably amount to about $\$ 50.5$ billion, as large an amount as in any year except the immediately preceding three.

Between 1951 and 1955, both prosperous years of relatively high employment, GNP, valued at 1954 prices, increased by $\$ 50.9$ billion from $\$ 341.8$ billion to $\$ 392.7$ billion. In the years $1951-54$, inclusive, total gross investment in fixed capital amounted to $\$ 196.4$ billion. Thus, assuming a one-year lag for the gestation of fixed capital investment, the marginal gross output-capital ratio for this period comes out to 25.9 per cent ( $\$ 50.9$ billion $+\$ 196.4$ billion). That is, it took approximately $\$ 4$ of gross investment to add $\$ 1$ to gross capacity output during this period. ${ }^{11}$ Assuming that the $\$ 220.9$ billion of gross investment which occurred in the years 1955 through

9. Average output per worker was calculated by dividing the GNP valued at 1954 prices by the sum of civilian employment and the armed forces.

10. Changes in output per man-hour in manufacturing follow a somewhat different pattern, but the exceptionally large increases in 1950 and 1955 and the small increases in 1956 and 1957 stand out here also (see Otto Eckstein, "Inflation, the Wage-Price Spiral, and Economic Growth," in The Relationship of Prices to Economic Stability and Growth [Compendium of Papers Submitted by Panelists Appearing before the Joint Economic Committee, 1958], pp. 361-74).

11. I have included residential construction in gross investment because the gross rental value of houses (including owner-occupied) is included in the gross national product. 
1958 was about as productive as the 1951-54 investment-i.e., that the output-capital ratio for these years was 25 per cent-and that the gains from this investment are realizable in 1959, the estimated capacity output for 1959 should be about $\$ 448$ billion at 1954 prices. Since the GNP price index in late 1958 is approximately 10.6 per cent above 1954, this would give us a value of about $\$ 495$ billion for 1959 valued at present prices.

Reasonable projections based upon probable growth of the labor force and change in output per worker lead to rather similar results. On the basis of the Census Bureau's recent projections of population, it appears that the non-institutional population in 1959 will be about 123.7 million. ${ }^{12}$ Assuming a labor force participation rate of 57.6 per cent-about the same as in the last four years-and assuming that 2.6 million persons are in the armed forces during the next year, the estimated civilian labor force for 1959 is 69.75 million. If the unemployment rate is 4.4 per cent, the same as in 1955 , this gives us a level of civilian employment of 66.7 million. Adding in the armed forces of 2.6 million gives total employment of 69.3 million. If this level of employment is achieved in 1959 and if output per employed person rises by 5.4 per cent as it did in 1955 , we will achieve a GNP of about $\$ 449$ billion at 1954 prices or $\$ 496$ billion at present prices. It will be noted that this is almost exactly the same as the estimate based on the growth of capital, which also assumed implicitly the 1955 level of unemployment since that year was used as the basis of the projection.

If we should achieve an unemployment rate below the 1955 level of 4.4 per cent or if productivity should increase more rapidly than the 5.4 per cent increase of 1955 , total output would, of course, be correspondingly higher. For example, if unemployment could be reduced to the 2.9 per cent level achieved in 1953 and if productivity should increase by 5.9 per cent as it did in 1950, we could reach a gross national product at present prices of about $\$ 506$ billion in 1959.

Although precision is obviously impossible in projections of this kind, I do believe that there are reasons for thinking that a level of total output in the neighborhood of $\$ 490-\$ 500$ billion is not an unreasonable expectation for 1959 if we can generate sufficient demand to absorb this volume of output. My reasons for believing this are, to summarize, the large increases in productivity we have experienced

12. Illustrative Projections of the Population of the United States, by Age and Sex 1960 to 1980 (Bureau of the Census, "Current Population Reports," Series P-25, No. 187 [November, 1958]), p. 16. 
in prior years of recovery from recessions; the very large volume of capital investment in $1955,1956,1957$, and 1958, which has not yet fructified in increases in output; the present relatively large volume of unemployment (5.9 per cent of the labor force on a seasonally adjusted basis in November); and the substantial increase in the labor force that can be expected next year.

Thus it appears to me that, insofar as the achievement of reasonably full utilization of capacity is concerned, the present situation calls for policies designed to increase aggregate demand rather than to restrict it. But what of the danger of inflation which worries so many people? Although it may seem paradoxical, I suggest that under present circumstances policies which encourage expansion may help to minimize inflation or at least may contribute very little additional fuel to it. It is interesting to note that the year 1955 when real output increased very sharply was not a year in which prices increased very much. On the basis of averages for the year, the consumer price index actually fell slightly between 1954 and 1955, while the wholesale price index rose less than 0.5 per cent and the implicit price deflator for GNP rose only 1.2 per cent. It is true that part of this relative stability in prices was due to the fact that farm prices fell-the implicit price deflator for farm GNP dropped by 6 per cent between 1954 and 1955. But the price level of all non-farm products -as measured by the implicit price deflator for the non-farm gross product-rose only 1.9 per cent. This compares with increases of 3.4 per cent in 1956 and 3.9 per cent in 1957 when productivity increases were much smaller. ${ }^{13}$

It appears that such inflation as there was in 1955 was due to rising demand and that it was not caused by increases in money wages in excess of productivity. Employment in non-agricultural establishments rose from 48.4 million in 1954 to 50.1 million in 1955 , while non-farm gross product, valued at 1954 prices, rose from $\$ 329.0$ billion to $\$ 357.2$ billion. On this comprehensive basis, annual output per worker rose by 5 per cent between the two years. During the same period total compensation of non-farm employees rose from $\$ 207.6$ billion to $\$ 223.9$ billion, and annual compensation per employee rose by 4.3 per cent. That is, for the non-farm sector of the economy as a whole, wages rose considerably less than productivity

13. Some of the inflation we have experienced in the last few years is undoubtedly fictitious, resulting from a serious upward bias introduced into our price indices by failure to make proper allowance for improvements in quality of goods and services (see Richard Ruggles and Nancy D. Ruggles, "Prices, Costs, Demand, and Output in the United States, 1947-57," in The Relationship of Prices to Economic Stability and Growth, pp. 297-308). 
in 1955. In 1956 and 1957, on the other hand, wage increases exceeded productivity increases by considerable margins.

On the basis of the 1955 experience, I suggest that if we succeed in getting large increases in output and productivity in 1959, the problem of cost-push from the wage side may not be serious. Moreover, if we follow excessively conservative policies with respect to demand, we may very well fail to realize the potential increase in productivity. If this is the case, the wage-push problem may be much more serious. Although our understanding of the causes of short-run changes in productivity is rather unsatisfactory, I believe an expansion of output will itself contribute to the increase in output per worker. In manufacturing industries during the recession of 1957-58 the reduction in production worker employment was relatively considerably larger than the reduction in total employment. It has been rather commonly pointed out that the recession produced drives to tighten up and increase efficiency in many companies. It seems likely that as production is increased, the increase in employment of supervisory personnel will be substantially less than in proportion to the increase in employment of production workers and the increase in physical output. Very likely, similar cases of decreasing real costs of production are to be found in many parts of the economy other than manufacturing and have much to do with the increase in labor productivity which seems to accompany the expansion of production.

Of course, it can scarcely be doubted that a rapid expansion in 1959 would be accompanied by some rise in the price level. However, this would be due to the rapid expansion of demand which would be necessary to achieve something like capacity output, and it seems at least a reasonable bet on the basis of past experience that the wage-push factor would be a less serious problem than it will be if we do not expand strongly. It may be noted that if a price rise in the neighborhood of 2 per cent is required to achieve the desired expansion, this will boost the required increase in monetary demand accordingly.

To summarize, I am suggesting that we are probably short of practicable full-capacity output for the year 1959 by something in the neighborhood of $\$ 40-\$ 50$ billion at current prices. The most optimistic forecast I have seen for 1959 is that we will achieve a GNP of $\$ 475$ billion. If this should happen and be accompanied by a 2 per cent rise in prices (which would boost my estimate of capacity output to something like $\$ 500-\$ 510$ billion at the new prices), we may fall short of capacity output in 1959 by roughly $\$ 25-\$ 35$ billion 
at 1959 prices or just slightly less at present prices. I believe this possibility should be borne in mind in the evaluation of our policies affecting aggregate demand.

\section{The Outlook for Monetary Policy}

Federal Reserve policy has become noticeably more restrictive in the last three months. This is evidenced by changes that have occurred in free reserves-the difference between aggregate excess reserves and member-bank borrowings. The level of free reserves is an index of credit conditions to which the System seems to attach considerable importance. For most of 1958 up to September, free reserves varied between $\$ 400$ and $\$ 600$ million. In early September, the amount dropped below $\$ 100$ million and with some variation has remained below that level since. On occasion for short periods, free reserves have become negative (i.e., there have been net borrowed reserves). The System has, it is true, increased its holdings of Treasury bills by approximately $\$ 1$ billion since September. However, there has been a decline in gold stock of nearly $\$ \frac{1}{2}$ billion, and a seasonal increase in currency in circulation has drained off a sizable amount of reserves. Thus, in a period of seasonal increase in credit demand, aggregate member-bank reserves have been held under tight control, with the result that the banks have reduced their excess reserves and increased their borrowings at the Federal Reserve. Short-term interest rates have risen rather steadily since midyear; the Treasury bill rate, which was below 1 per cent in July, is now close to 3 per cent, and other short-term open-market rates have increased accordingly. Federal Reserve discount rates at 2.5 per cent are nearly $\frac{1}{2}$ per cent below the bill rate; if the bill rate remains at its present level for very long or rises still higher, it seems certain that the discount rate will be raised, probably to 3 per cent.

Long-term interest rates fell quite sharply during the period of declining activity from the peaks reached in September and October, 1957, reaching their low points in April-June, 1958. Since that time they have risen steadily and sharply; by September they had reached levels comparable with the 1957 highs. Recently they have risen still higher. Thus long-term rates began to rise while short-term rates were still falling and while monetary policy as measured by the level of free reserves was still relativey easy. This paradoxical situation is explained partly by the speculative debacle that disorganized the market for Treasury securities in the middle of the year and by the fact that expectations of another round of inflation apparently be- 
came widespread in financial circles as soon as some signs of recovery began to appear. Expectations of rising interest rates have made long-term bonds relatively unattractive and have thus kept down the supply of long-term funds. Some of the funds thus released have doubtless gone into the short-term market, thus restraining to some extent the rise in short-term rates. Thus, while long-term rates are in some cases above their 1957 peaks, short-term rates are still substantially lower than they were at that time. Fear of rising commodity prices has also quite obviously caused a shift of funds from the bond to the stock market, with the result that dividend price ratios have recently been below the yields on long-term Treasury bonds. Another factor contributing to high long-term yields is the continuing large volume of new offerings of bonds by corporations and state and local governments. Recent further increases in yields on Treasury bonds seem to be the result of a feeling in the market that the Treasury will attempt to tap the long-term market in connection with its projected January cash borrowing.

Thus we find ourselves in a relatively tight credit situation-at least according to recent standards-at a time when, if my estimates are even approximately correct, we still have a considerable distance to go to achieve full recovery. What lies ahead for monetary policy? There may well be some easing of credit conditions-or at least a slackening of the pace of restriction-in the early part of 1959 as a result of the usual seasonal decline in demand for credit, the payingoff of seasonal credits, and the return of currency to the banking system which normally follows the Christmas buying rush. However, if the Treasury should take advantage of such easing as tends to occur in January to offer a long-term bond, this move could serve to sustain the pressure. And, in general, unless either the economic outlook or the views of our monetary managers undergoes a change, $I$ think we can expect a continuation and probable accentuation of the restrictive monetary policy of recent months. Evidence of this is to be found in the statement made by Chairman Martin a few days ago in which he evidenced great concern about the problem of inflation, indicating that in his view this is the major economic issue of the day, and recommending to the Administration that it take prompt measures to raise taxes or reduce government spending. ${ }^{14}$ This statement certainly does not suggest any letup in the policy of restriction.

I believe that the fear of inflation that prevails in some quarters is much greater than is justified by a reasonable interpretation of the facts of the present situation, as indicated earlier in this paper. For

14. Wall Street Journal, December 15, 1958, p. 6. 
this reason, $I$ believe that a moderate increase in aggregate demand would be a good thing for the economy. Unfortunately, it seems to be rather difficult to accomplish such an increase in the immediate future by means of monetary policy. There is considerable-though perhaps not conclusive-evidence that most categories of incomegenerating expenditures are not very sensitive to such changes in interest rates and credit conditions as can be brought about promptly by moderate use of monetary policy. ${ }^{15}$ In addition, recent studies suggest that the time lag between changes in credit conditions and such impact as they may have on expenditures is likely to be rather long-averaging perhaps a year or more. ${ }^{16}$ Thus a reasonable readjustment of monetary policy might have relatively little direct effect on expenditures, and we might run some risk that such effects as it did have would be so long postponed as to occur when they would do more harm than good:

There are further problems which stem from the inflationary "set" that characterizes present expectations. Given these expectations, any dramatic easing of credit might be interpreted as presaging a dangerous spiral of prices. The result might be a prompt and exaggerated impact on financial markets-particularly on the stock market-the ultimate effects of which could be rather dangerous. The Federal Reserve was probably mistaken in permitting-even encouraging-credit to tighten as much as it has in the last few months. In particular, I believe it would have been desirable to keep long-term interest rates from rising as much as they have. Of course, with the weapons it is presently using, it would have been difficult for the System to prevent the rise in long-term rates without flooding the economy-particularly the banking system-with liquidity. Moderate purchases of long-term securities, properly timed, could surely have prevented long-term rates from rising so much. Moreover, long-term purchases could have been offset by short-term sales if the effect on bank reserves proved to be greater than was appropriate. But with the System operating only in bills, rather large purchases would probably have been necessary, and the effects would have been uncertain at best.

Under the present circumstances, I believe the monetary authori-

15. For a further discussion of this see Warren L. Smith, "Monetary Policy and the Structure of Markets," in The Relationshtp of Prices to Economic Stability and Growth, pp. 493-511.

16. See Milton Friedman, "The Supply of Money and Changes in Prices and Output," in The Relationship of Prices to Economic Stability and Growth, pp. 241-56; Thomas Mayer, "The Inflexibility of Monetary Policy," Review of Economics and Statistics, XL (November, 1958), 358-74; F. Gehrels and S. Wiggins, "Interest Rates and Fixed Investment," American Economic Review, XLVII (March, 1957), 79-92. 
ties should proceed rather cautiously. A sharp and pronounced easing of credit would be rather risky. However, it would probably be desirable for the System to avoid further restriction until recovery has progressed further than it has to date. In fact, while I recognize the problem of lags, I believe a moderate easing of credit would be worth trying if it could be accomplished without setting off a burst of speculation. From a longer-run point of view, since a high rate of investment is vital to our growth and in the course of time makes a contribution to the fight against inflation by raising productivity, the wisdom of a policy which pushes interest rates to ever higher levels seems very doubtful. If interest rates continue their upward trend, they are certain to have an eventual impact on capital formation.

Recent experience indicates that changes in credit conditions can have rather strong effects on residential construction and mortgage credit, and I believe that this may create problems in the next few months. This area is quite sensitive to changes in long-term interest rates-although with a lag of several months-because of the existence of interest ceilings on FHA-insured and VA-guaranteed mortgages. When interest rates on alternative investments, such as corporate and state and local government securities, rise substantially above these rate ceilings, the supply of funds available for mortgage financing is diverted into the higher-yielding investments, and residential construction is starved for funds. However, one factor that may make this problem a little less serious than it was in 1956 and 1957 is the fact that VA-guaranteed mortgages are a somewhat less important factor now than they were at that time, while FHAinsured mortgages have assumed a more important role. The regulations of the Veterans Administration which prevent the builder from passing on mortgage discounts to the ultimate buyer of the property have made VA-guaranteed mortgages particularly vulnerable to tightening credit conditions. There is greater flexibility with respect to discounts on FHA-insured mortgages, and the increased importance of the FHA program may, therefore, have reduced the extreme sensitivity of residential construction to changes in long-term interest rates. Nevertheless, I believe that this is still the most creditsensitive sector, and, while housing has been a relatively strong factor in the recovery so far, I fear that it may soon be adversely affected by the prevailing high interest rates.

Finally, it may be noted that the liquidity of the banking system is considerably less ample at the present time than it was in late 1954, the last time the Federal Reserve embarked upon a restrictive 
policy. At that time the banking system possessed such large supplies of government securities that it was able to carry out a tremendous expansion of credit to the private sector by shifting the composition of its portfolios from government securities to loans. Because of these circumstances, the restrictive policy appears to have been very slow to exert appreciable effects on the supply of bank credit to the private sector. Although bank liquidity was increased substantially during the recent period of easy money and consequently a considerable amount of portfolio shifting may again be possible, $I$ believe there is reason to expect that the banks and their borrowers will feel the credit pinch somewhat sooner this time if credit continues to be tightened. 